\title{
OM GRUNDTVIG-UDGAVER
}

Af Steen Johansen.

Da der for tiden er bestræbelser $i$ gang for at faa paabegyndt en samlet, videnskabelig udgave af N. F. S. Grundtvigs skrifter, kunde det maaske være af interesse at betragte de eksisterende store udvalgsudgaver lidt nøjere og undersøge deres tekstudgivelsesprincipper, som naturligt nok maa afspejle vigtige sider af Grundtvigforskningens historie. Som indledning meddeles en lille oversigt over Grundtvigs forhold til sine forlæggere og forlag.

I.

Et eftersyn af forlagsangivelserne $i$ de af Gr. selv udgivne bøger giver til resultat, at Gr. $i$ længere perioder har været knyttet til følgende fem forlag eller forlæggere: Andreas Seidelin, J. Fr. Milo (ejeren af Wahls boghandel), C. A. Reitzel, C. G. Iversen (Michaelsen og Tillge) samt Karl Schønberg. Hvad han ikke udgav hos disse, udkom spredt hos flere forskellige, saaledes $\mathrm{f}$. eks. hos Schubothe (Maskeradeballet 1808, Nordens Mytologi 1808, Optrin af Nordens Kæmpeliv I-II, 1809-11, Nordens Mythologi 1832 og 1870), A. Schmidt (Danne-Virke II-IV, 1817-19; bd. I, 1816, udgav Gr. selv) eller E. L. Thaarup (Fest-Psalmer fra og med 1870). Derudover udsendte Gr. talrige, som regel mindre skrifter eller lejlighedsdigte i kommission eller helt privat, og blandt bogtrykkerne kan da nævnes P. H. Høeckes Enke, J. H. Schultz, C. Græbe, Louis Klein, Fabritius de Tengnagel, Thiele, Bianco Luno og især J. D. Qvist. Saaledes var Nyaars-Morgen 1824 et privattryk (Schultz); Danskeren I-IV 1848 -51 udkom til at begynde med i kommission hos boghandler Eibe og trykt hos Louis Klein, siden alene hos Qvist. En særstilling indtog originaludgaverne af Saxo- og Snorreoversættelsen, som begge tryktes af Schultz og pekuniært støttedes af Selskabet for de nordiske Oldskrifter (og iøvrigt var en subskriptionsudgave), men alligevel udgaves og forhandledes af Gr. privat. (Dette betød dog ikke, at Gr.s hjem fik karakter af en boglade; hans efterhaanden ikke faa 
privat forlagte skrifter forhandledes til enhver tid af den, der paa det givne tidspunkt var hans hovedforlægger).

Kgl. Hof- og Universitetsbogtrykker Andreas Seidelin (17771840) var Gr.s hovedforlægger ca. 1808-1820, idet hans sidste selvstændige bog af Gr. blev Bjowulfs Drape 1820; dog trykte han ogsaa flere lejlighedsdigte for Gr. efter nævnte aar. Enkeltheder om Gr.s forhold til Seidelin savnes uheldigvis ganske; navnlig vilde visse økonomiske oplysninger have interesseret os. Hvorledes formaaede Seidelin f. eks. i 1814 at udsende otte og i 1815 seks forskellige bøger af Gr., altsaa i alt fjorten skrifter i løbet af blot to aar? Forklaringen er sikkert ikke den, at Gr., der jo i disse aar var tjenstledig kapellan og levede meget fattigt, har kunnet tilskyde penge til bøgernes udgivelse; og da ikke faa af skrifterne var rent polemisk bestemte, bortfalder ogsaa, i det mindste delvis, forklaringen: kamp for levebrødet. Der er da kun én forklaring tilbage, nemlig at Gr. allerede da har været en saa anset forfatter og til stadighed har kunnet regne med en læserkreds stor nok til, at dens køb af hans bøger har kunnet dække de nødvendigste omkostninger. Dette udelukker ikke, at Gr. kunde opleve salgsfiaskoer (f. eks. med »Krønikens Gienmæle« 1813), men i det store og hele maa det have forholdt sig saaledes, hvilket ogsaa bekræftes af litteraturhistorien. Gr.s tilhængere har dengang som senere $i$ hans liv været saa trofaste, at han bogstavelig talt aldrig har kendt til vanskeligheder med at faa sine skrifter antaget til trykning.

Seidelins afløser blev boghandler og bogbinder Jacob Frederik Milo (1795-1865), som i 1822 var blevet ejer af sin afdøde svigerfader N. A. Wahls boghandel. Med sin broder Johan Milo i Odense som kompagnon (vistnok et rent formelt forhold) bragte J. Fr. Milo »den Wahlske Boghandling « frem til et anset forlag med religiøse skrifter som speciale, og ved i 1825 at vove udgivelsen af de første hefter af det af Gr. og Rudelbach redigerede Theologisk Maanedsskrift blev han snart Gr.s (og efter ham adskillige Grundtvigtilhængeres) forlægger; hans første selvstændige bog af Gr. var Kirkens Gienmæle 1825, hans sidste: Nyaars-Ønske i Danske Samfund 1843, hvortil dog samme aar kom tredie hefte af bd. III af Haandbog i Verdenshistorien og i 1846 sjette oplag af Historisk Børne-Lærdom. Heller ikke om Gr.s forhold til Milo er vi synderlig oplyst. Det faldt i Milos (og bogtrykker Græbes) lod at udgive Gr.s hovedværker Christelige Prædikener eller Søndags-Bog 1827-30, Sang-Værk I-II 1837-41 og største delen af Haandbog i Verdenshistorien (1833 ff.), og han har saaledes medvirket betydeligt til at give Gr. hans typografiske »ansigt《 for eftertiden. Til Milos ros maa det siges, at han 
har haft heldet med sig; hans Gr.-bøger er smukt, læseligt og sobert trykte, og ikke mindst titelbladene ofrede han megen opmærksomhed.

I 1841 trak Milo sig tilbage fra sin forretning, som blev ført videre af E. Skouboe. Denne afviklede i 1849 det Wahlske forlag, som dermed ophørte; men allerede i 1843 var Gr. gaaet over til C. A. Reitzel, vore guldalderdigteres berømte forlægger.

Gr.s første bog hos C. A. Reitzel (1789-1853) var det Skandinaviske Selskabs udgivelse af hans tale »Om Nordens Historiske Forhold《 1843, den sidste blev det lille skrift »Om KæmpeviseBogen $\ll$, oktober 1847. Forbindelsen med Reitzel varede saaledes kun 4-5 aar, og hos ham fik Gr. bl. a. udgivet Brage-Snak 1844, det saakaldte »Prøvehefte《 1845, Danske Ordsprog og Mundheld 1845 og Danske Kæmpeviser til Skole-Brug 1847, alle bøger trykt saa moderne, som det dengang var muligt. Desværre er vi uvidende om det personlige forhold mellem Gr. og Reitzel, og Otto B. Wroblewski, som i sit skrift »Ti Aar i C. A. Reitzels Boglade《 (1889) fortæller mangt et træk om vore nationale digteres færden hos Reitzel i 1840'erne, meddeler desværre ikke en eneste erindring om Gr.

Under Treaarskrigen udgav Gr. baade Danskeren og talrige flyveskrifter i kommission, men i 1850 bragte udgivelsen af det første hefte af festsalmerne ham i forbindelse med boghandler og bogforlægger C. G. Iversen, hvis firma skulde blive Gr.s forlag i den kommende halve snes aar. Formidleren har maaske været C. J. Brandt, for hvem Iversen i 1848-49 udgav hans to bind Rim og Sange, hvori Br. fik optaget flere originaldigte af $\mathrm{Gr}$.

C. G. Iversen (1817-1881) havde i 1846 nedsat sig som boghandler og forlægger i København. I 1857 flyttede han til Kolding, men overdrog forinden sin forretning til sin svoger E. S. Tillge, som i forening med Th. Michaelsen førte den videre som »C. G. Iversens Boghandel. (Michaelsen \& Tillge) « eller »Th. Michaelsen \& Tillge. (C. G. Iversens Boghandel) «. Da Michaelsen udtraadte i 1869, blev det til »C. G. Iversens Boghandel. (E. S. Tillge)«. Paa Iversens eller hans efterfølgeres forlag fik Gr. bl. a. udgivet de første syv oplag (1850-56) af Fest-Psalmer ${ }^{1}$ ) samt bogudgaven 1860 af Christenhedens Syvstjerne. En særlig indsats var Iversens udgivelse af 2.-4. udgave af Saxooversættelsen (1855 og senere) og 2. udgave (1865) af Snorreoversættelsen samt begge binds udgivelse under fællestitlen Høinordens Rigskrøniker fra Middelalderen. Ved at lade hver af disse oversættelser trykke $\mathrm{i}$ eet bind i oktav, modsat hvert af origi-

1) 1.-5. oplag udgaves af Gr. privat, men forhandledes hos Iversen. For 6 . og 7. oplag var Iversen regulær forlægger. 
nalernes tre svære kvartbind, har dette forlag sikkert bidraget meget til værkernes videre udbredelse. Først nu fik de et virkeligt folkeligt format og blev solgt til folkelige priser.

At dømme efter et par forlagskataloger synes Iversens forlag (speciale: religiøse og historiske skrifter) at have haft sin blomstringstid i 1850'erne, vel antagelig saa længe Iversen selv ledede foretagendet, altsaa til 1857. Under efterfølgerne Michaelsen $\mathcal{E}$ Tillge er det tydeligt nok gaaet noget tilbage med firmaet; $i$ alle tilfælde formaaede det ikke at holde fast ved Gr., som omkr. 1858-59 blev erobret af en ung, driftig og dygtig forlægger, der tillige var grundtvigianer, nemlig Karl Schønberg.

Karl Schønberg (1832-1908) havde i 1857 etableret sig som forlægger i København. Det første af Gr., han udgav, var anden udgave 1859-60 af Søndags-bogen, Gr.s største prædikensamling. Derefter fulgte slag i slag foruden nye skrifter af Gr. en lang række nye udgaver af ældre bøger. Af de nye kan f. eks. nævnes Beowulfes Beorh 1861, Den levende Røst 1863, Budstikke i Høinorden 1864 (og flere andre smaaskrifter af Gr. fra samme aar) samt Kirke-Speil 1871; af nyudgaver (eller bogudgaver af tidligere artikelserier i tidsskrifter) f. eks. Optrin af Nordens Kæmpeliv I-II 1861, Haandbog i Verdenshistorien I-III 1862-69, Skal den Lutherske Reformation virkelig fortsættes? 1863, Om den sande Christendom og Om Christendommens Sandhed 1865, Den christelige Børnelærdom 1868. Og i forening med Iversens forlag, der fra tidligere tid havde en slags forret til Gr.s salmer, udgav han (dog med pekuniær støtte udefra) Psalmer og aandelige Sange I-III 1868-73 (bd. IV-V, 1875-81, udgav Schønberg alene). Efter Gr.s død fortsatte Schønberg med nye udgaver af Gr.s Ordsprog, Kæmpeviser, Brage-Snak, MandsMinde-foredragene, Kirke-Speil osv., ligesom han ogsaa med aarene blev forlægger for de fleste af datidens betydelige grundtvigianere som Vilh. Birkedal, C. J. Brandt, Fr. Barfod, Ludv. Schrøder, Fr. Rønning o. fl. (jvf. Dansk biogr. Leksikon, art. Karl Schønberg). I 1880 tilbød han Svend Gr. og C. J. Brandt udgivelsen af deres paatænkte udgave af Gr.s Poetiske Skrifter, et tilbud, der fra forlæggerens side var et vovestykke, men som betegnede kulminationen af hans idealistiske begejstring for $\mathrm{Gr}$. Han lod den da ogsaa fremtræde $i$ et meget smukt, gedigent og moderne udstyr, man sammenligne den blot med den omtrent samtidige andenudgave af $\mathrm{H}$. C. Andersens Samlede Skrifter eller Fr. Paludan-Müllers Poetiske Skrifter! - At Schønberg ogsaa udgav grundtvigske vennemødeberetninger, prædikensamlinger og højskolesangbøger var en selvfølge. 
En samlet betragtning af Gr.s produktion i hans egen levetid synes at vise, at den m.h.t. det bogkunstneriske, bogudstyrsmæssige har været helt paa højde med samtiden, naar man vel at mærke erindrer, at Gr. ikke var fiktionsdigter, men historisk-folkelig og kirkelig skribent. De Seidelinske bøgers unægtelig noget pauvre udstyr har næppe været værre eller bedre, end hvad andre bogtrykkere har kunnet yde lignende litteratur $\mathrm{i}$ aarene omkring statsbankerotten. De lysere tider, der fulgte efter, satte deres præg paa bøgerne, hvilket ogsaa ses i Gr.s produktion, jvf. f. eks. den smukke udgave af Nordens Mytologi 1832! - Af førsteoplagene af Gr.s bøger tryktes hyppigt et mindre antal eksemplarer paa bedre papir (skrivepapir, tykt papir, velin) foruden de sædvanlige salgseksemplarer paa trykpapir; det gælder saaledes om Saxo- og Snorre-oversættelserne, samt vistnok om alle de større bøger af Gr., som Milo og Schønberg udsendte; ogsaa af Seidelin vides der at være trykt enkelte paa bedre papir (Nytaarsnat, Kvædlinger, Bjowulf-oversættelsen). Skrivepapirseksemplarernes tekst synes hos Gr. altid at være identisk med de tilsvarende trykpapirseksemplarer, og det skyldtes ganske særlige omstændigheder, naar Gr. i skrivepapirseksemplaret af Sang-Værk I 1837 indførte en række smaaforandringer i teksten, se herom min Bibliografi over N. F. S. Gr.s Skrifter II, 1950, s. 17 f. (Om en lille afvigelse paa titelbladene til en del af oplaget af Saxo- og Snorreoversættelserne $1818-22$, se s. st. bd. I s. 146 og 150). Dog maa en kommende videnskabelig Gr.-udgave naturligvis overalt have opmærksomheden henvendt ogsaa paa dette forhold for at sikre sig den helt autentiske tekst.

Vedrørende oplagenes størrelse og salget af Gr.s bøger i hans levetid, saa kan maaske følgende sparsomme oplysninger være af interesse, skønt de kun mindre vedkommer vort emne. Først skal fremhæves, at vi normalt har ringe eller ingen viden om orig.-oplagenes eksemplarantal. Rent tilfældigt veed vi dog f. eks., at Verdenskrøniken 1812 tryktes i 450 eks., og at Psalmer ved Jubel-Festen 1817, Bjowulf-oversættelsen 1820, Nyaars-Morgen 1824 og Kirkens Gienmæle 1825 alle tryktes i 500 eks. hver, hvilket jo giver et fingerpeg m.h.t. andre af Gr.s større bøger fra disse aar ${ }^{2}$ ). Men hvad vi ikke veed, men meget gerne vilde vide, var $\mathrm{f}$. eks. antallet af subskri-

2) Om det indviklede forhold vedrørende eks.-antallet af Saxo- og Snorreoversættelserne 1818--22, se bibliografien bd. I s. 150. - Om eks.-antallet af Gr.s viser og sange i anledning af Frederik VI's død, se bibliogr. bd. II s. 160 , og om antallet af visse viser og flyveblade $i$ april-juni 1848, se s.st. s. 333 fodnote. 
benter paa Danne-Virke I-IV 1816-19 og paa Sang-Værk I 1837, af abonnenter paa Danskeren I-IV 1848-51 og f. eks. størrelsen af oplaget af Nordens Mythologi 1832. En nøje undersøgelse af Gr.arkivet paa det $\mathrm{kgl}$. Bibliotek vil dog maaske engang kunne bringe enkelte oplysninger frem herom. - Af en bevaret haandskreven fortegnelse (ved Michaelsen $\mathcal{E}$ Tillge) over restoplagene af Gr.s skrifter fremgaar det, at der saa sent som i 1858 endnu henlaa partier af bl. a. følgende ældre værker (i parentes efter titlen angives eksemplarantallet): Roskilde-Riim (134), Roskilde-Saga (36), Verdenskrøniken 1814 (50), Verdenskrøniken 1817 (180), Litteratur-Tidendens Skudsmaal (164), Bjowulfs Drape (80), Nyaars-Morgen (238), Kirkens Gienmæle (3. opl., 1825) (3), Kong Harald og Ansgar (41), Christelige Prædikener eller Søndags-Bog (15), Den danske Stats-Kirke upartisk betragtet (155), Phenix-Fuglen (60). Af mange af de senere smaaskrifter fandtes derimod af hvert kun omkring et halvt eller helt dusin eller højst en snes eksemplarer tilbage, det gælder f. eks. om Bøn og Begreb, Kiærminder, Skjalde-Blik, Tale til Folke-Raadet, Udkast til en ny Trykkelov, Skov-Hornets Klang, Om ReligionsForfølgelse osv. osv. - Denne liste blev grundlaget for en forøget trykt liste paa 4 sider, som Schønberg i 1859 tilstillede subskribenterne paa 2. udg. af Søndagsbogen. Her har Sch. faaet samlet vistnok alt, hvad der er bevaret af restoplag (dog uden angivelse af eksemplarantal), og det ses da, at man foruden de førnæunte (dog fraregnet Søndagsbogen, som altsaa maa være blevet udsolgt i 1858-59) endnu $i 1859$ har kunnet erhverve førsteudgaverne af bl. a. Maskeradeballet i Dannemark 1808, Optrin I-II 1809-11, Bibelske Prædikener 1816 og Snorreoversættelsen 1818-22. Af Gr.s skrifter fra og med ca. 1830 har man kunnet købe praktisk talt alt bortset fra Sang-Værk I-II 1837-41 samt visse krigssange fra 1848. (Som nævnt forefandtes mange af skrifterne kun i smaa restoplag). - Men i resten af Gr.s levetid, altsaa i løbet af 1860 'erne, ændredes dette fuldstændigt. I 1873 var førsteudgaverne af alle bøger for 1850 udsolgt paa nær følgende 12: Hvorfor kaldes vi Lutheraner? 1812, Hvad skal vi giøre ... etc. 1813, En mærkelig Spaadom 1814, Fædrene-Aaret 1815, Om Religionsforfølgelse 1842, Danske Folke-Fester 1842, Om Nordens Historiske Forhold 1843, Skov-Hornets Klang 1844, Udkastet til en ny Trykkelov 1845, Græsk og Nordisk Mythologi 1847, Nordens Historiske Minder 1847, Om Kæmpevise-Bogen 1847. Dette veed vi fra en af Karl Schønberg til Svend Grundtvig i 1873 stilet lille haandskreven opgørelse over restoplagene, som han slutter med ordene: »Malling i Kristiania ejer »Nordiske Smaadigte« (1838), som 
imidlertid vist nok snart bliver udsolgt.« - Af en trykt bogliste fra 1869 fremgik det, at man da endnu kunde købe Verdenskrøniken 1817 og Nyaars-Morgen 1824, der altsaa i Gr.s levetid har været de to trægest afsættelige blandt hans ældre hovedværker. Men i 1873 var som antydet ogsaa disse $\mathrm{udsolgt}^{3}$ ).

»Sent, men sødt,《 skal Gr. have sagt om sit personlige liv. »Sent, men ikke for sent, « kan man sige om Gr.s forfatterliv. Det er bekendt, at Gr. først »slog igennem« som offentlig personlighed temmelig sent, nemlig i slutningen af 1830 'erne, da han nærmede sig de 60 aar. Det er sikkert rigtigt at hævde, at der for den tid - bortset fra sensationerne omkring dimisprædikenen 1810, Kirkens Gienmæle 1825 og ansættelsen ved Frederikskirken 1832 - alt i alt herskede temmelig stor stilhed om Gr.s virke som forfatter maalt med den københavnske litterære offentligheds maalestok. Men i Christian VIII's tid ændredes Gr.s position til det modsatte; fra da af regnedes han for en af nationens store, $i$ klasse med Thorvaldsen og Oehlenschläger og feteret som disse. Og med den ydre fremgang fulgte en ikke ubetydelig succes som forfatter. I de sidste 12-13 aar af sit liv maatte han besørge en række nyudgaver af de betydeligere af sine ældre bøger, foruden at han modtog pekuniær støtte til en samlet udgave af salmerne. Den for religiøse sager ellers temmelig ligegyldige dagspresse i København begyndte at ofre ham ekstra opmærksomhed; den gav plads for vennemødereferater, og i 1865 offentliggjorde Fædrelandet en af Clemens Petersen affattet stor forsideanmeldelse af en religiøs bog af Gr., nemlig andenudgaven (= første bogudgave) af Om den sande Christendom og Om Christendommens Sandhed. Gr. noterede sig denne anmeldelse som en personlig sejr og takkede samme aar for den i sit eget organ Dansk Kirketidende. - Bogmæssigt fortsatte den grundtvigske højkonjunktur (med forlov af dette ord) endnu en 10-12 aar efter Gr.s død, hvor en række medhjælpere, der havde bistaaet ham med udgivelserne $\mathrm{i}$ hans alderdom, førte disse videre og blev grundlæggerne af Gr.-forskningen eller Gr.-filologien.

3) Helt nøjagtig har Schønbergs opgørelse fra 1873 ikke været, thi af et par af hans senere kataloger fremgaar det, at man i 1876 endnu kunde købe det af Gr. privat udsendte skrift »Bededags-Tale for Rigsdagen 1848, og at Sch. endnu i 1884 har haft eksemplarer til salg af »Lykønskning til Danmark « 1845, opr. udsendt hos Reitzel. I hans opgørelse er heller ikke indbefattet enkelttryk af digte samt visse flyveblade fra omkr. 1848. 
II.

Svagsynethed hos Gr. som ældre nødte ham til at benytte fremmed hjælp ved forberedelsen til andenudgaver og overhovedet ved udgivelsen af bøger. Skønt denne hjælp ikke altid alene har bestaaet i korrekturlæsning, men ogsaa i flere tilfælde har været af mere selvstændig art (jvf. nedenfor), saa underligt nok hverken takker eller paa anden maade nævner han disse hjælpere i de diverse forord eller efterskrifter, naar undtages et eneste værk, nemlig Beowulfes Beorh 1861, hvor Gr. udtrykte sin glæde over den bistand, han havde modtaget af professor Stephens og af sin søn Svend Gr. - Vi veed, at Gr. som medhjælpere til udgivelsen af de to første bind af Psalmer og aandelige Sange 1868-70 havde C. J. Brandt, Chr. Kragballe og Kr. Køster, som vistnok afløste hinanden, saaledes at Køster til sidst var enemedhjælper (jvf. F. Rønning: C. J. Brandt, 1892, s. 145). Til udgivelsen af Kirke-Speil 1871 (som var en førsteudgave efter forf.s manuskript) fik Gr. hjælp af Køster, som dog døde, mens bogens trykning stod paa, hvorefter biblioteksassistent Weeke fortsatte udgivelsen. Desuden har Køster, der jo var Gr.s kapellan i Vartov, uden tvivl været hans hovedmedhjælper ved de mellem 1862 og 1870 udkomne oplag af og tillæg til Fest-Psalmer. Smaaskrifter om den historiske Høiskole 1872 udgaves af Carl Grove i forening med Gr., ligesom ogsaa Gr. naaede at medvirke ved tre af Trier, Nutzhorn, Schrøder o. fl. udgivne højskolesangbøger, som udkom 1872-74. Som nævnt var ogsaa Gr.s søn Svend Gr. sin faders medhjælper, maaske den betydeligste af dem alle. Herom siger Ludv. Wimmer følgende i Fr. Barfods mindeskrift over Sv. Gr. 1883, s. 18: „Ved siden af sin egen store litterære virksomhed har Sv. Grundtvig også haft en meget væsentlig andel $i$ besørgelsen af nye udgaver af sin faders skrifter både $i$ de sidste 16 år af dennes liv (1856-72) og efter hans død.« Om enkeltheder i denne virksomhed før Gr.s død er vi saa temmeligt uvidende. Af nogle breve fra Gr. i 1861 til Sv. Gr., som da midlertidigt opholdt sig i Jylland, erfarer man, at Gr. underrettede sin søn om, hvordan det gik med tilrettelæggelsen af nyudgaven 1861 af Optrin I-II, desuden ønskede han f. eks. at opsætte aftalen med Schønberg om den nye udgave af Middelalderens Historie, indtil Sv. Gr. var kommet tilbage til København. Dette kan tyde paa, at der til stadighed har været et fortroligt litterært samarbejde mellem faderen og sønnen, og at denne sidste har fungeret som en slags sekretær for ham. Vor formodning bestyrkes af et utrykt brev fra Sv. Gr. i 1872, hvor han omtaler sig som den, »hvem han (॰: N. F. S. Gr.) i en række år benyttede som hjælper og mellem- 
mand ved udgivelsen af sine skrifter«. - For nutidens Gr.-forskning er hele dette medhjælperspørgsmaal ved andenudgaverne i Gr.s levetid saa temmelig underordnet, da forskningen jo altid holder sig til førsteudgaver, medens andenudgaverne kun har interesse, hvis Gr. har ændret $\mathrm{i}$ disse, hvad der undertiden er tilfældet. I andenudgaverne imødekom $\mathrm{Gr}$. ofte tidens krav til mere læselig, en mere moderne udseende tekst. Netop til dette formalistiske arbejde havde han medhjælperne, fremfor alt sin søn Svend Gr., som vel uden tvivl har været den, der stod bag den yderst lempelige ortografiske afpudsning af andenudgaverne af Haandbog i Verdenshistorien 1862 -69 og af nyudgaven 1870 af Nordens Mythologi. Disse lempelser før 1872 (f. eks. reduktion af spatieringer, bindetegnssammensatte ords sammenskrivning til eet ord) maa ikke forveksles med den generelle retskrivningsforandring i næsten alle Gr.s skrifter efter 1872, hvorom nærmere i det følgende.

Efter Gr.s død blev med Karl Schønbergs ord (i et utrykt brev) varetagelsen af Gr.s litterære efterladenskab lagt i prof. Svend Gr.s og pastor Brandts hænder. Dermed begyndte for alvor Gr.-filologien i dette ords videste betydning; udgivelsen af efterladte papirer tager fart, og man kan da tale om Gr.-forskningens forste periode, der gaar til ca. 1880, det aar, da Poetiske Skrifter, som indleder den følgende (psykologisk-biografiske) periode, begynder at udkomme. Til denne første periode hører fremfor alt pastor J. Kr. Madsen, som i 1873-81 fuldførte den første samlede udgave af Gr.s salmer. Andre, langt mindre omfangsrige tekstudgivelser (hovedsagelig i blade og tidsskrifter) besørgedes i disse aar f. eks. af Fr. Barfod, Ludv. Schrøder, N. W. T. Bondesen, Fr. Nygård, Th. Graae, Fr. Nielsen, S. Birket Smith ofl., men da ingen af dem var Gr.-udgivere i større stil, skal de ikke nærmere behandles her ${ }^{4}$ ).

Efter Køsters død 1871 overdrog Gr. personligt førnævnte pastor Madsen, tillige forstander for Jelling Statsseminarium, at fortsætte udgivelsen af Psalmer og aandelige Sange, hvoraf bd. I-II var udkommet i 1868-70. Madsen fortæller, at han fik udleveret en mængde

4) Allerede medens Gr. levede, var de første spirer til en litterær Gr.-forskning dukket op. I Dansk Folketidende 1867 havde Brandt saaledes offentliggjort tre vers af Gr. fra 1838, og i 1869 havde H. Bech udgivet en mindebog om pastor Gunni Busck, hvori der for første gang tryktes privatbreve af Gr. Paa en maade bidrog ogsaa Gr. selv litterært til at opklare sin egen fortid, idet han villigt fandt frem et eller andet gammelt, utrykt digt, naar venner bad ham om bidrag. Saaledes fik prof. Rasmus Nielsen hidtil ukendte ungdomsdigte af Gr. trykt i sit tidsskrift $\gg$ For Ide og Virkelighed « 1870; aaret forud havde Sv. Gr. offentliggjort andre ukendte digte af sin fader i samme tidsskrift. 
manuskripter, hvoriblandt en stor del hidtil utrykte salmer, ca. 400 . »Af disse sidste gjennemgik jeg i det sidste Halvaar af Gr.s Levetid henimod Halvdelen sammen med Gr. selv, der saaledes kom til at lægge sidste Haand paa dem enten ved at billige dem uforandret, eller ændre dem, eller vrage dem«. Gr. ønskede, at salmerne i bd. III skulde ordnes efter kirkeaaret, medens bd. IV skulde rumme salmer, der hørte til sakramenterne og til kirkelige lejlighedshandlinger m. v. Til ingen af bindene naaede Gr. dog at udpege, hvilke salmer der skulde med, og dette besørgedes da af Madsen, ofte under samraad med Svend Gr. og C. J. Brandt, hvorefter bd. III udkom i 1873 med titlen »Kirke-Aaret i Salme-Sang《 og bd. IV i 1875 med titlen »Kristen-Livet i Salme-Sang«. Et tillægsbind »Efterslæt af Grundtvigs Salmesang « fulgte i 1881, hvori ogsaa fandtes et af Madsen udarbejdet udførligt variantapparat til alle fem bind.

Hvad der imponerer en læser af disse af Madsen udgivne bind er ikke alene den megen flid og viden, der er nedlagt i kildeoplysninger, variantapparat og registre, men det er især den grundighed, hvormed den grundtvigske plan er ført igennem i bd. III og IV! Det er virkelig lykkedes udgiveren at beherske disse 2 binds $i$ alt 696 salmer, saaledes at han har kunnet ordne 396 salmer i bd. III efter kirkeaaret, med en gruppe salmer til hver eneste af aarets sønog helligdage fra advent til advent, medens han i bd. IV har ordnet 300 salmer i grupper som »Ordet《, »Forsagelsen«, »Første Trosartikel«, »Daaben«, »Synd og Naade«, »Konfirmation« osv. osv. Det siger sig selv, at han ved ordningen af salmerne $\mathrm{i}$ bd. III har haft de sikreste holdepunkter, nemlig kirkeaarets perikoper, medens grænserne har været mere flydende i bd. IV, jvf. herom Madsens forord s.st. Udgiveren har været klar over, at indholdet af bd. IV, der jo især behandler den dogmatisk-opbyggelige side af kristendommen, er beslægtet med første halvdel af bd. I, der ogsaa overvejende er koncentreret om dogmerne. Det er for den sags skyld ogsaa beslægtet med »Trinitatis-delen « ( $\supset$ : sidste halvdel omtrentlig) af bd. III. (Derimod er sidste halvdel af bd. I, hele bd. II og forste halvdel af bd. III alle indbyrdes beslægtede, idet der i disse fortrinsvis besynges den historiske side af kristendommen).

Som man ser, er den af J. Kr. Madsen gennemførte ordning i bd. III og IV ganske uhistorisk i litterær henseende, dvs. i henseende til digtenes offentliggørelse eller - subsidiært - affattelsestid. Det synspunkt: at opfatte og aftrykke salmerne som litterære dokumenter med sondring mellem, hvad Gr. selv offentliggjorde, og hvad han lod ligge uudgivet, dukker slet ikke op. Alt er indholdsbestemt ligesom Gr.s egen ordning af salmerne i bd. I og II var det. Ogsaa m. h.t. 
de enkelte salmers opsætning har M. baaret sig ad omtrent som Gr. selv i bd. I: alle salmernes oprindelige overskrifter (for saa vidt de har haft saadanne) er fjernede, saa at salmerne kun taler til læseren om dele af den helhed, hvori de er anbragt.. Dog har han markeret grupperne ved indskudte gruppe-overskrifter (i bd. III kirkeaarets helligdage, i bd. IV de fornævnte inddelingstitler), medens Gr. i bd. I af Sangværket suverænt udelod alle inddelinger, til nogen desorientering for læserne. (Om de inddelinger eller grupper, hvori salmerne i Sangv. I kan deles, se bemærkningerne i min bibliografi bd. II, 1950, s. 18).

Ved ordningen af bd. V, Efterslæt-bindet, har udgiveren dog ladet litterære synspunkter komme noget til sin ret: salmerne har saaledes her deres oprindelige titler, hvis saadanne findes, eller de har faaet en af udgiveren formet titel i parentes; ogsaa affattelsesaarstal er paaført. I tre af de fire tillægsgrupper er salmerne trykt kronologisk; men da paa den anden side alle fire grupper er tillægsgrupper til de foregaaende indholdsordnede bind, formindskes værdien af den sidstnævnte forbedring noget. Madsens variantapparat lider af den grundskavank, at han fortrinsvis lægger en given salmes sidste form til grund for angivelsen af afvigelser, med andre ord, heller ikke her er ordningen historisk-litterær, som nutiden vilde kræve det. Variantapparatet har derfor været til liden glæde for en senere tids Gr.forskere trods dets iøvrigt store grundighed.

Af det foregaaende følger, at nutiden naturligvis maa afvise hele opstillingen af salmerne i bd. III-V af den gamle Sangværk-udgave, da den ikke skyldes Gr., men en udgiver. Hvordan man saa ellers bedst bør aftrykke Gr.s store salmeskat (forudsat man ønsker den aftrykt særskilt), er et andet og meget problematisk spørgsmaal. (Om ordningen i den nye Sangværk-udgave $1944 \mathrm{ff}$. , se i det følgende). - Endelig er den gamle salmeudgave ogsaa utilfredsstillende p. gr. af dens ensrettede, moderniserede (og nu forældede) retskrivning, et punkt, der fortjener særskilt omtale.

Madsen lod bd. III-V trykke i den Svend Grundtvig'ske retskrivning, som med ministeriel anbefaling var den herskende ca. 1872-90. Og for at gøre hele Sangværket ensartet paa dette punkt udkom i 1873 ogsaa bd. I og II med samme retskrivning. Nu var der dengang, i slutn. af $1860^{\prime}$ erne, almindelig enighed om, at den gamle Molbech'ske ortografi burde afløses af en mere tidssvarende, spørgsmaalet var blot, hvor radikalt man skulde reformere. Her sejrede den af professor Svend Gr. foreslaaede ortografi, som de forskellige Gr.-udgivere, Sv. Gr. inclusive, straks tilegnede sig og øjeblikkelig ogsaa udstrakte til Gr.s egne tekster. Spørger man, hvorfor 
de gjorde dette, er det sikkert ikke nok at svare med en henvisning til den daværende dannede almenheds krav i al almindelighed, thi man kunde jo tværtimod godt tænke sig, at Gr.-udgiverne f. eks. havde fæstet sig ved det konservative, det traditionsbundne hos Gr., eller ved det ærværdigt-historiske i hele hans gerning, og de kunde da være kommet til den opfattelse, at netop Gr.s salmer, sange og prædikener var det sidste, der burde moderniseres. Men naar udgiverne i stedet for skyndte sig at modernisere (og højskolefolkene gik et langt skridt videre, idet de valgte »Stockholmermødets《 radikale nordisk-danske retskrivning af 1870), saa hænger dette uden tvivl sammen med, at datiden, altsaa 1860-70'erne, i høj grad følte Gr. som hørende deres egen tid til; hele den af ham baarne bevægelse kulminerede i disse aartier, den var en aktuel, livskraftig realitet, skønt dens stifter efter almindelige menneskekaar at regne allerede forlængst var en olding. Under saadanne forhold var det en selvfølge, at Gr.s forfatterskab, og da specielt den folkeligste side deraf, salmerne og sangene, maatte iklædes tidens ortografi. Forøvrigt maa den Svend Grundtvig'ske retskrivning betegnes som en lempelig modernisering i forhold til den gamle, og saa længe Gr.filologien endnu befandt sig paa begyndelsesstadiet, voldte dette forhold ingen særlig skade. En senere tids Gr.-forskning med dens skærpede krav til nøjagtige tekster har derimod ofte maattet beklage sig over, at den i mange tilfælde har skullet benytte Gr.-tekster trykt $i$ en form, der hverken var Gr.s eller nutidens. Særligt generende har det været, at Svend Gr. valgte og konsekvent gennemførte denne retskrivning i Poetiske Skrifter $1880 \mathrm{ff}$., som ellers paa andre omraader indledte en ny periode i Gr.-forskningen.

Vi skal ikke her fordybe os særligt i litteraturhistorikeren pastor C. J. Brandt's virksomhed som Gr.-udgiver. Hans nære venskab med den grundtvigske familie gav ham, efter at han i 1872 var blevet ansat ved Vartov, rig lejlighed til studier i Gr.s efterladte papirer med beredvillig tilladelse til at lade dem aftrykke. Det var især Gr.s kirkelige gerning og salmedigtning, der havde hans interesse. Resultatet blev en smuk række særskilte udgaver: 11.-17. oplag (187389) af Fest-Psalmer, Prædikener af N. F. S. Gr. i Frederiks-Kirken 1832-39 (1875), Kirkelige Leilighedstaler af N. F. S. Gr. (1877), 3. udg. (1879) af Gr.s En liden Bibel-Krønike for Børn og Menigmand, N. F. S. Gr.s Sidste Prædikener. I Vartov Kirke 1861-72. I-II (1880), Bibelske Prædikener . . . ved N. F. S. Gr., 2. udg. (1883), meget forøget, og endelig en forkortet udgave i et bind (1883) af Salmer og aandelige Sange. Br. blev desuden medhjælper ved udgivelsen af sjette bind (1885) af Gr.s Poetiske Skrifter og eneudgiver 
af syvende bind (1889) af samme, begge dog udgivet paa grundlag af afdøde Sv. Gr.s forarbejder og efter hans principper. Endvidere offentliggjorde Br.til stadighed andre efterladte papirer af Gr.i Dansk Kirketidende, hvis stifter og redaktør han var. Paa denne maade saa adskillige digte, breve, enkelte prædikener, skrivelser, udkast osv. lyset. Ofte aftrykte Br. blot disse tekster uden eller næsten uden ledsagende oplysninger, undertiden offentliggjorde han dem som led i detailstudier i Gr.s liv.

Af denne flittige litterære virksomhed fremgaar klart, at $\mathrm{Br}$. i sit forhold til Gr. efter dennes død først og fremmest var udgiveren. Med sine udgaver har han uden tvivl paa samme gang tilsigtet at tjene grundtvigianismen og videnskaben. Alle sine Gr.-tekster lod han derfor fremtræde i datidens retskrivning, den førnævinte Svend Grundtvig'ske; men samtidig var han en overordentlig samvittighedsfuld udgiver, litterært skolet som faa andre af datidens litterære grundtvigianere. For denne videnskabelige aand, der gennemtrænger alle hans udgaver og afhandlinger, har den senere Gr.-forskning været ham megen tak skyldig.

Det blev Brandts opgave at omredigere Vartovsalmebogen, da det 11. oplag skulde udsendes i 1873. Den noget kaotiske ordning af salmerne i de af $\mathrm{Gr}$. selv udgivne 10 første oplag erstattede $\mathrm{Br}$. med en planmæssig dogmatisk-historisk ordning $\mathrm{i}$ tilslutning til kirkeaaret, selv om salmerne forblev de samme. Iøvrigt var $\mathrm{Br}$. en fremragende salmehistoriker og selv lidt af en salmedigter.

III.

Medens J. Kr. Madsen og C. J. Brandt som udgivere fortrinsvis syslede med den kirkelige side af Gr.s forfatterskab (begge var præster), blev Svend Grundtvig (1824-83, professor i nordisk sprog og litteratur) i væsentlig grad udgiver af den ikke-kirkelige del af sin faders digtning. Om han har »kæmpet« for sine nyudgaver paa dette omraade kan ikke siges med sikkerhed, men umuligt er det ikke. Gr. selv udgav som ældre hverken nogen samlet udgave eller noget udvalg af sine mange »verdslige digte (det sidste af ham selv besørgede udvalg var Nordiske Smaadigte 1838), men gik i stedet for mere og mere op i sin kirkelige gerning, højskolebevægelsen, kamp for danskhed og folkelighed etc., og det blev især foredragsvirksomhed, politik og salmeudgaver, der optog ham mest i alderdommen. Det kan ogsaa her erindres, at man i talerne ved Gr.s begravelse temmelig ensidigt fremstillede den afdøde som en kirkens mand, saa 
ensidigt, at det gav anledning til kritik bagefter. Der var altsaa for Svend Gr. grunde nok til at gøre offentligheden opmærksom paa, at hans fader ogsaa var digter i dette ords egentlige betydning, og det første, han selvstændigt udgav af sin fader, blev da to i 1869 og 1870 udkomne smaa antologier, nemlig »Digte« 1869 (2. oplag samme aar) og »Folkelæsning. Kirkelig og folkelig Digtning« 1870. (Ogsaa eksemplarer alene med titlen »Kirkelig og folkelig Digtning« findes). Derefter fulgte i 1875 tredie udgave af Krønike-Riim og samme aar anden udgave af Danske Ordsprog og Mundheld. I 1876 besørgede han andenudgaverne af Kirke-Speil og Brage-Snak. I 1877 fulgte hans udgave af Gr.s historiske foredrag fra 1838, med den af Gr. selv skabte titel Mands Minde; i 1880 udgav han bd. I og II af Gr.s Poetiske Skrifter ${ }^{5}$ ), bd. III og IV udkom i 1882, og i samme aar kom ligeledes hans udgave af Gr.s og Ingemanns brevveksling. I jubilæumsaaret 1883 udgav han tredie udgave baade af Christenhedens Syvstjerne og af Den christelige Børnelærdom og var om sommeren samme aar i fuld gang med arbejdet paa udgivelsen af bd. V af Poet. Skr., da han uventet for alle døde efter en kun kort forudgaaende sygdom. Korrekturlæsningen af de resterende forholdsvis faa ark af bd. V besørgedes derefter af hans svoger, daværende arkivassistent J. Bloch.

Samtidig med denne livlige udgivervirksomhed var Sv. Gr. som før omtalt raadgiver for J. Kr. Madsen ved dennes udgave af Psalmer og aandelige Sange og havde ogsaa taget initiativet til den af C. J. Brandt i 1883 besørgede forkortede udgave i eet bind af hele salmeværket. Af bevarede haandskriftkopier i Gr.-arkivet fremgaar det desuden, at Sv. Gr. har næret planer om udgivelsen af yderligere andre skrifter af Gr.; desuden var det bekendt, at han ogsaa engang agtede at nedskrive en biografi over sin fader, om hvem han vidste mere end nogen anden dalevende, selv om denne viden for største delen laa begravet $i$ hans hukommelse. Intet under derfor, at hans død blev saa dybt beklaget, som tilfældet var.

Om den videre udgivelse af Poet. Skrifter kun dette: Afsætningen af de hidtil udkomne fem bind blev - trods anmeldelsernes lovord - temmelig ringe, til forbavselse baade for forlæggeren og mange andre. (Allerede straks efter udsendelsen af bd. I og II havde man mærket dette). Og nu meldte sig ved Sv. Gr.s død tillige spørgsmaalet om et passende udgiveremne. Heldigvis havde Sv. Gr. efterladt

5) Var oprindelig tænkt at skulle foreligge afsluttet $\mathrm{i}$ otte bind til hundredaaret for Gr.s fødsel, 1883. Det lykkedes dog hverken at overholde aarstal eller bindtal. 
sig omhyggelige forarbejder til de følgende bind, hvad der i høj grad lettede vanskelighederne. I 1885 udkom da bd. VI, besørget af Sv. Gr.s enke fru Laura Gr., med bistand af C. J. Brandt. I 1889 udsendtes bd. VII, besørget alene af C. J. Brandt. Samme aar døde Br., aaret efter døde Gr.-papirernes ejer fru Asta Gr. (og i 1891 fru Laura Gr.), hvorved udgivelsen bragtes til standsning for lange tider. Hovedaarsagen til værkets standsning har dog næppe været disse dødsfald, men antagelig tilbageholdenhed fra forlagets side; med syv bind var grænsen naaet, hvortil forlæggeren kunde strække sig uden støtte. Omkr. 1890 var tillige den føromtalte grundtvigske højkonjunktur forlængst forbi; i tiden ca. 1890-1920, Brandesianismens og naturalismens epoke, var interessen for $\mathrm{Gr}$. herhjemme uden for kirkelige kredse ganske minimal. I 1920'erne begyndte en ny opgang, og det lykkedes da Holger Begtrup, føreren i en ny generation af Gr.-forskere og -udgivere, at skaffe de fornødne penge til veje til fuldførelsen af Poet. Skrifter ${ }^{8}$ ). Bd. VIII udkom da i 1929, udgivet af seminarieforstander, mag. art. Georg Christensen; aaret efter fulgte bd. IX, ligeledes udgivet af Georg Christensen. Udgivelsen af Poet. Skr. havde saaledes taget nøjagtig 50 aar.

En omtale af Sv. Gr. som udgiver af sin faders skrifter maa begynde med udskillelsen af de to førnævnte smaa antologier fra 1869 og 1870; de danner en gruppe for sig, netop fordi de udsendtes, medens Gr. levede. Hvad Sv. Gr. udgav efter sin faders død, kan passende deles $\mathrm{i}$ to grupper: diverse enkeltudgaver samt Poetiske Skrifter.

I antologierne 1869 og 1870 er retskrivningen samtidens og altsaa tilsyneladende identisk med Gr.s egen; det er jo før reformen sætter ind, og nutidens læsere af antologierne fristes derfor uvilkaarlig til at tro, at digtene ogsaa er nøjagtige og komplette aftryk af originalerne. Et nærmere eftersyn viser noget andet: udgiveren har foretaget ikke faa moderniseringer i stavemaaden (spurgdes > spurgtes, Soel $>$ Sol olgn.), alt dog meget nænsomt og uden at omstøde det gamle præg i ortografien; til gengæld er tegnsætningen langt mere ændret, og talrige spatieringer, der udgør et saa karakteristisk og ejendommeligt træk i alt, hvad Gr. har skrevet, bortset fra en vis periode i ungdomsaarene, er forsvundet; desuden er adskillige digte gengivet $i$ forkortet skikkelse, uden at det i 1869-antologien meddeles i de enkelte tilfælde, og hvis $\mathrm{f}$. eks. flere læsemaader kendes til et digt, kan udgiveren undertiden foretrække en

6) Samtidig skaffede han ogsaa penge til brevudgaven 1924-26 og til udgaven af Vartovsprædikener 1924. 
senere læsemaade fremfor originalen, uden at han oplyser dette. $\mathrm{Nu}$ betød alt dette dog ikke meget i disse kun rent populære udvalg af Gr.s poesi. Bøgernes sigte var rent folkeligt, ikke videnskabeligt.

I 1872 dør Gr., og samme aar udkom Sv. Gr.s retskrivningsordbog med den nye, af ministeriet anbefalede ortografi. Vi har tidligere anført den aktuelle grundtvigianisme som den formentlige hovedaarsag til, at alle Gr.-udgiverne i Gr.s nære vennekreds straks derefter lod Gr.s egne tekster fremtræede i den nye retskrivning. Vi er uvidende om Sv. Gr.s personlige mening om denne overgang. Skjuler hans tavshed et nederlag? Det er ikke utænkeligt, at den med nøjagtige tekstudgaver ellers meget fortrolige videnskabsmand har maattet bøje sig for forlæggeren eller eventuelt fru Asta Gr. i retskrivningsspørgsmaalet $\mathrm{i}$ hans faders skrifter. Faktum er i alle tilfælde, at i de følgende aar kom samtlige udgaver ved Sv. Gr., ogsaa den store udgave af Poet. Skrifter, helt og holdent i den nye retskrivning, uden at Sv. Gr. motiverede hvorfor.

Moderne litteraturforskning stiller et uomgængeligt krav til nøjagtige tekster; som følge deraf er forskeren henvist til enten at arbejde direkte med originaludgaverne og direkte med digterens eventuelle efterladte papirer, eller han maa arbejde med nøjagtige aftryk af værkerne og papirerne. Dette krav om nøjagtige aftryk er i vor tid naturligvis i lige grad rettet mod formens og indholdets nøjagtighed, medens i ældre tid kravet om den helt nøjagtige ydre form (॰: ortografien) var mindre skarpt. Lægger man i dag lige saa stor vægt paa nøjagtig form som paa nøjagtigt indhold, saa maa alle Svend Gr.s udgaver af sin faders værker kasseres; slækker man derimod paa formkravet, har hans udgaver stadigvæk betydelig værdi. Ligesom C. J. Brandt var ogsaa Svend Gr. en trænet og dygtig udgiver, der absolut aldrig leverede sjusket arbejde. Naar man blot erindrer sig den ændrede ortografi, reduktionen af spatieringer (evt. indførelse af nye spatieringer), ændringerne i tegnsætning olgn., saa er hans enkeltudgaver af Krønike-Riim, Brage-Snak, Kirke-Speil, Christenhedens Syvstjerne osv. fortræffelige. Det samme gælder ogsaa om de udgaver, der er baseret paa efterladte papirer alene, altsaa Mands Minde og Gr.-Ingemanns brevveksling. (Dog vil nutiden ofte hos Sv. Gr. savne helt eksakte oplysninger om Gr.s efterladte papirer i de respektive tilfælde; han giver $f$. eks. aldrig nøjere manuskriptbeskrivelser, og vi svæver ofte i uvidenhed, om haandskriftmaterialet nu ogsaa er helt udtømt). Ogsaa hans indledninger til de to sidstnævnte værker har den dag i dag betydelig værdi, selv om den allernyeste Gr.-forskning nu ogsaa truer dem med forældelse. 
Hvad nu selve de Poetiske Skrifter I-IX angaar, saa maa man for at bedømme udgaven kritisk først erindre sig Sv. Gr.s diverse hensigter med den. I indledningen i bd. I oplyser han bl. a., at han har villet levere en tilnærmelsesvis fuldstændig samling af Gr.s poesier, dog med udelukkelse af hans særlige kristelige digtning, som forelaa $\mathrm{i}$ en anden udgave (Psalmer og aandelige Sange). Kravet om fuldstændighed modificerer han dog i samme indledning til, at han af Gr.s utrykte digte (i bd. I) kun medtager »saadanne, som forelaa fuldt færdige fra Forfatterens Haand, saa at det ofte kun kan skyldes et Tilfælde, at de ikke alt ere trykte for 70. Aar siden «. Det kan med det samme oplyses, at udgiveren ikke fastholdt dette princip i de senere bind, hvor ikke faa brudstykker olgn. blev aftrykt. Men bortset herfra, hvorledes forholdt det sig saa med fuldstændigheden for de hidtil utrykte digtes vedkommende? $\mathrm{Nu}$ er det givet, at udgaven betød et vældigt skridt fremad paa dette omraade, men alligevel gælder det her, som det for blev sagt om Sv. Gr.s særudgaver: læseren føler sig utryg over for den tilsyneladende fuldstændighed; Sv. Gr. underretter aldrig sine læsere tilstrækkeligt om sit materiales tilstand, han ytrer heller aldrig nogen tvivl om muligheden af at overskue Gr.s samtlige poetiske efterladenskaber; den ukyndige læser maa uvilkaarlig gaa ud fra, at Sv. Gr. behersker det hele, og at læseren faar det hele. $\mathrm{Nu}$ ved vi, at Sv. Gr. i Poet. Skr. f. eks. undlod at trykke mange helt private digte af familiehensyn, men han oplyser det ikke i udgaven ${ }^{7}$ ). Naar saaledes det første digt $\mathrm{i}$ bd. I er et (tidligere trykt) digt fra 1807 (udtaget af en prosaafhandling), og det første hidtil utrykte digt i samme bind er fra 1808 (PS I 27 f.), saa faar den almindelige læser det fejlagtige indtryk, at 1807-08 var de aar, hvori Gr. begyndte at skrive vers af ikke-kirkelig karakter. Har Sv. Gr. da været uvidende om sin faders poetiske forfatterskab før 1807? Maaske! Ganske vist havde C. J. Brandt i Dansk Kirketidende 1873 offentliggjort visse poesier af Gr. fra hans skoletid; disse rim kunde dog Sv. Gr. meget vel have fundet uværdige til optagelse i Poet. Skr. Men nu digtene i dagbøgerne fra studentertiden og især i optegnelserne fra Langeland! Muligvis er Sv. Gr. gaaet i sin grav uden at kende dem, idet fru Asta Gr. meget vel kan have nægtet ham (specielt ham) adgang til dem. Det vides, at Gr.s efterladte papirer i 1873 gav anledning til et spændt forhold mellem fru Asta Gr. paa den ene side og Sv. Gr. og hans helsøskende paa den anden. For saa vidt kan man sige, at Poet. Skr. som videnskabelig udgave betragtet kom alt for tidligt til verden, og at Sv. Gr. rimeligvis er uskyldig i den

7) Det siges først af Georg Christensen i efterskriften i bd. IX. 
her paatalte mangel vedrørende tiden før 1807. Men i 1888 synes visse familiehensyn underligt nok at være faldet bort, thi da udkom brevvekslingen mellem Gr. og Chr. Molbech, hvori adskillige digte fra 1804-07 første gang saa lyset (foruden flere meget aabenhjertige breve af Gr.), og hvorved følgelig bd. I af Poet. Skr. blev forældet. Ogsaa Sv. Gr.s alt for tidlige død kan fremføres til hans undskyldning; hvis han havde oplevet værkets afslutning, fuldført af ham selv i samme tempo som ved værkets begyndelse, havde han maaske $i$ et supplementbind raadet bod paa manglerne. - Foruden familiehensyn gjorde ogsaa forlagshensyn afbræk i fuldstændigheden. Krønike-Riim blev saaledes udeladt, fordi Sv. Gr. selv faa aar i forvejen havde genudgivet dem særskilt; af samme grund blev Bjowulfs Drape udeladt. Overfor spørgsmaalet om medtagelse af oversættelser og gendigtninger gik udg. alt for summarisk til værks, idet han udelod (næsten) alle oversættelser uden at betænke, at han derved bibragte læseren et ufuldstændigt billede af Gr.s poetiske virksomhed (og en drøftelse af grænserne mellem blotte oversættelser og mere omskrevne gendigtninger indlod han sig ikke paa). For saa vidt var udeladelsen af Bjowulf konsekvent nok, men hvorfor da optage »Phenix-Fuglen«, som ogsaa var en oversættelse? Jo, for her gjorde forlagshensyn sig ikke gældende, da det næavnte værk ikke var blevet udgivet siden 1840. Skønt Poet. Skr. kun skulde indeholde ikke-kirkelig digtning, fandt ogsaa salmer undertiden indgang i værket, se f. eks. PS I 288-291, 301-304, V 1-3, 455-470, 536--539, VII 7477, jvf. ogsaa VI 580-581, som dog først en senere tid har tilegnet sig som salme. Svend Gr. var dog (jvf. hans indledning i bd. I s. XII) ganske klar over det vanskelige $i$ at gennemføre en streng sondring mellem religiøse og ikke-religiøse digte hos Gr., og han har sikkert haft sine særlige grunde til disse salmers medtagelse, hvad han dog p. gr. af sin tidlige død ikke naaede at meddele sine læsere, se herom J. Blochs efterskrift i bd. V.

Angaaende fuldstændigheden m. h. t. optryk af tidligere trykte (э: af N. F. S. Gr. offentliggjorte) digte, saa er Poet. Skr. (naar man ser bort fra grænseomraaderne oversættelser og salmelignende digte) en temmelig fuldstændig udgave; dette er netop dens store styrke, hvorfor den da ogsaa har været overordentlig nyttig for ikke at sige uundværlig for Gr.-forskningen. At der kan forekomme enkelte fejlagtige kildehenvisninger er vel uundgaaeligt, og det kan da ogsaa en sjælden gang hænde, at et digt, skønt tidligere trykt, angives som »hidtil utrykt« (det gælder saaledes f. eks. PS VI 567-569, VIII $58 \mathrm{ff}$., $286 \mathrm{ff}$., 296 f.), eller udgiveren kan have glemt at optrykke et (tidligere trykt) originaldigt (vistnok kun een gang: bibliogr. nr. 
739) eller undladt at skænke afvigende former, varianter, tilstrækkelig opmærksomhed. Men alt dette er smaating over for selve den indsats, der er gjort ved at samle digtene; baade Gr.-forskningen og dansk aandsliv i sin helhed har i høj grad aarsag til at være Sv. Gr. og hans efterfølgere som udgivere taknemlige.

Foruden at levere en fuldstændig udgave var det ogsaa Sv. Gr.s hensigt at levere en saa vidt mulig biografihistorisk udgave, hvilket vil sige, at han optrykte digtene $i$ den orden, i hvilken forfatteren havde produceret dem (ikke: offentliggjort dem). Det har været udgiverens (udgivernes) ideal at faa affattelsestiden konstateret for alle digtes vedkommende for dermed at etablere deres »rette《 rækkefølge. Derfor nummererede Sv. Gr. digtene i hvert bind. Denne opstillingsmetode var i nøje samklang med de moderneste strømninger i datidens aandsliv (realismen, naturalismen), som i litteraturforskningen forkastede den aldre tids idealistisk-systematiske litteraturvurdering og -ordning efter genrer og satte et nyt, individuelt bestemt syn paa digteren i stedet for, hvor værkerne alene opfattedes som personlige aftryk af digterens liv og følgelig burde trykkes i den rækkefølge, de blev til. Selv om Sv. Gr. vistnok ikke har udtalt sig om sit teoretiske syn paa disse grundspørgsmaal, saa har han gennem sin udgave leveret i det mindste materialet til en saadan opfattelse af Gr.s digtergerning, en opfattelse, som efter Sv. Gr. i høj grad blev taget op og uddybet af Gr.-forskere som f. eks. Fr. Rønning og Holger Begtrup. - Ved at aftrykke Gr.s skrifter efter affattelseskronologien, »skrivebordskronologisk«, var Sv. Gr. vistnok den første herhjemme, der praktiserede en saadan metode paa en guldalderdigter, man tænke blot paa genre-ordningen f. eks. i Liebenbergs Oehlenschläger-udgave eller 2. udgave af $\mathrm{H}$. C. Andersens Samlede Skrifter!

Nutiden maa afvise Sv. Gr.s opstillingsform, hvis hovedfejl er den, at den ignorerer en mængde litterære fakta og følgelig giver læserne et falsk eller i det mindste forvirret indtryk af digteren. Man erkender nu mere klart end tidligere, at det i samlede videnskabelige udgaver galder om at genskabe samtidigheden (saa vidt muligt), saaledes at en digters læsere faar meddelt eller »serveret《 teksterne i samme rækkefølge og om muligt i samme udstyr, som digterens samtid fik det. Dette er naturligvis et ideal, som kun delvis lader sig realisere. Men lader man digtene vandre direkte fra digterens skrivebord ind i 》Samlede Værker《 paa deres affattelseskronologiske sted, overspringer man oftest en mængde vigtige ting, der tjener til forstaaelse af digtene og af forfatteren. I en nutidsudgave maa derfor originaludgavernes udgivelsestid (ikke: affattelsestid) danne ryg- 
raden, ogsaa for digtere som $\mathrm{f}$. eks. Gr., for hvem udgivelsestiden (og undertiden ogsaa udgivelsen overhovedet) nu og da spillede en mindre rolle. Og med fremhævelsen af den »publikationelle« side af forfatterskabet maa følge respekt for de af digteren frembragte helhedskompositioner. Selv om de enkelte digte i en digtsamling kan være skrevet til vidt forskellig tid (og fortalen maaske er skrevet sidst), saa maa en nutidsudgave genskabe disse helheder og ikke, som Sv. Gr. gør det, splitte dem ad af affattelseskronologiske hensyn. Den, der paa grundlag af Poet. Skr. ønsker at vide, hvad f. eks. Gr.s digtsamlinger »Heimdall«, »Saga« eller »Kvædlinger« indeholder, vil faa et ikke ringe besvær dermed, selv om samtlige samlingers digte naturligvis findes i udgaven. Gr.s digtsamlinger var tilmed i høj grad helhedskompositioner, ikke tilfældige sammenstykninger af digte.

Sv. Gr.s metode førte følgelig til, at trykte og utrykte digte behandledes forskelsløst, de aftryktes i en fortsat strøm, hvad der litterært var og er forkasteligt, jvf. ovenfor. Nutiden maa kræve, at det utrykte materiale bliver udskilt og gengivet for sig, men den nærmere ordning af dette materiale vil nok saa meget være et praktisk som et principielt spørgsmaal, selv om en historisk bestemt ordning altid vil være den rigtigste.

Naar Georg Christensen i efterskriften til bd. IX har kaldt Poetiske Skrifter for en hverken fuldstændig eller en videnskabelig udgave (modsat af, hvad Sv. Gr. mente), saa har han, jvf. ovenfor, ret i denne paastand af endnu flere grunde end de af ham selv anførte (normaliseringen, ufuldstændigheden). Enkelte andre uvidenskabelige træk kunde ogsaa paapeges, f. eks. Sv. Gr.'s egenmægtige omredigering af tekster (Ps. VI 377-380, se specielt Sv. Gr.'s ord s. 378 øverst; ogsaa i samme bind s. 536-540; ogsaa andre steder i udgaven), men denne uvane forblev dog hos ham paa kimstadiet. Desværre mangler Poet. Skr. et afsluttende fællesregister, en mangel, som nævnte værk deler med ikke faa andre af vore klassikerudgaver (incl. Grundtvigudgaver).

\section{IV.}

Siden Psalmer og aandelige Sange (1868 ff.) og Poetiske Skrifter (1880 ff.), der hver for sig tilstræbte en art fuldstændighed paa deres omraade, er der ikke fremkommet udgaver af lignende karakter bortset fra den i 1944 paabegyndte fuldstændige udgave af Gr.s salmer 
(jvf. i det følgende). Det har været udvalg altsammen. Nu afgiver studiet af udvalgsudgaver i almindelighed ikke megen editionsmæssig belæring for kendere af de »udvalgte《 forfattere, og overfor en kritik af udvalgene har de respektive udgivere tillige ofte garderet sig i forord eller indledninger. Store udvalgsudgaver, der har et videre sigte end det rent merkantile, og som $i$ almindelighed er foranstaltede af litterære fagfolk, kan dog ikke let unddrage sig faglig kritik. En saadan skal dog for Gr.s vedkommende ikke gives i det følgende, hvor der blot skal peges paa et par hovedtræk belyst ud fra det foregaaende. Det drejer sig om følgende: Holger Begtrups udgave af Udvalgte Skrifter I-X (1904-09) (her forkortet: US), Georg Christensen og Hal Kochs udgave af Værker i Udvalg I-X (1940-49) (forkortet: VU) og Sang-Værk I ff. (1944 ff.), ved en salmekomité.

I udgaver fra det 20. aarhundrede af danske klassikere har det føromtalte litterært-kronologiske princip efterhaanden vundet frem paa bekostning af det ældre yderliggaaende psykologisk-biografiske princip og det endnu ældre genre-bestemte princip. Eneherskende bliver det litterært-kronologiske princip kun i faa tilfælde, normalt brydes det til stadighed med de aldre principper, og de fleste større udvalgsudgaver betegner gerne ligesaa mange kompromis'er mellem de forskellige principper. Begtrups Gr.-udvalg er i hovedsagen en ægte litteratur-kronologisk udgave, med aftryk af teksterne i originalens form og paa originalens plads. (NB. dog US IX 331-595, X 83-362, der ikke er gengivet i orig.s retskrivning). Det er en behagelighed at vide og erfare, at bd. I indeholder skrifter fra Gr.s ungdom og bd. X skrifter fra hans alderdom, hvad der i lignende udgaver ikke altid er tilfældet for andre forfatterers vedkommende! Skønt Begtrup indføjer inedita (ungdomsdagbøger, Dansk RavneGalder) paa deres affattelseskronologiske plads, virker det ikke forstyrrende, da hans udgave kun rummer forholdsvis faa inedita. (Men hvis der $\mathrm{i}$ alle bindene havde eksisteret hyppige indskud af efterladte papirer, vilde udgaven have været mislykket, litterært betragtet). - Modsat denne forholdsvis rene litterær-kronologiske linie i US brydes i Værker i Udvalg flere editoriske principper. Historisk ordning krydses af genreordning, og for prosaskrifters vedkommende brydes den historiske ordning af indholdsbestemte tendenser. Bd. VII-VIII indeholder et kronologisk udvalg af ikke-kirkelige digte $1808-72$, bd. IX $-\mathrm{X}$ et lignende udvalg af religiøse digte 1810 -70; for at finde frem til f. eks. en »aandelig sang« skal man da søge to 
steder, og undertiden finder man da ogsaa digtet to steder $!^{8}$ ) $\mathrm{Nu}$ kan det $\mathrm{i}$ en folkelig udgave naturligvis være praktisk at have digtene samlet separat, men ordningen af de øvrige skrifter burde da have været rent historisk, hvilket dog ikke er tilfældet i VU, man undersøge blot indholdet af bd. III-V! Da der findes orienterende indledninger i hvert bind, er følgen ofte den, at man maa gennemlæse eller søge $\mathrm{i}$ flere indledninger for at faa fuldstændig oplysning om et givet afsnit af Gr.s liv. - Begtrups mange indledninger udmærker sig ved korthed (undertiden er de lidt for summariske) og resumerer blot den nødvendigste viden; i VU er indledningerne i virkeligheden at betragte som særskilte afhandlinger, der kræver særlig bedømmelse, hvilket ikke skal gives her. Heller ikke paa en kritik af udvalget som saadan skal jeg indlade mig $^{9}$ ).

I den nye Sangværk-udgave, hvis tekster udmærker sig ved ypperlig nøjagtighed (modsat den gamle udgaves normalisering), genoplives ejendommeligt nok den gamle Svend Grundtvig'ske biografiskpsykologiske, hyperkronologiske ordning i bd. III ff. Salmerne trykkes alle forskelsløst efter affattelsestiden, uden at der i bindene selv gives meddelelse om, hvad Gr. selv offentliggjorde, og hvad han lod ligge uoffentliggjort. Et kommentarbind vil naturligvis til sin tid oplyse om disse forhold og derved lette den litterært indstillede Gr.forsker, som forhaabentlig i samme bind vil finde et fællesregister over alle salmernes begyndelseslinier. Iøvrigt har udgiverne gjort et uhyre grundigt og fortjenstfuldt arbejde paa at tilvejebringe den rette affattelseskronologi, saaledes at udgaven ogsaa (og ikke mindst) paa dette punkt ganske gør den gamle udgave forældet.

Naar jeg til sidst skal sammenfatte mine indtryk af editionsprincipperne i de eksisterende udvalgsudgaver af Gr.s skrifter, saa kan jeg kun modificerende gentage, hvad jeg før skrev om udvalgsudgaver i almindelighed: for kendere af Gr.s produktion, den trykte og den utrykte, er der kun forholdsvis ringe belæring at hente $i$ disse udgaver, naar det gælder planlæggelsen og redigeringen af og tekst-

8) Jvf. VIII 47 f. og IX 110 f., VIII 113 ff. og IX 448 ff., VIII 408 f. og X 275 f., VIII $428 \mathrm{ff}$ og X $315 \mathrm{ff}$., VIII $432 \mathrm{f}$. og X $289 \mathrm{f}$., VIII $439 \mathrm{f}$. og X $328 \mathrm{f}$.

9) Ogsaa i VU aftrykkes saa vidt muligt originalteksterne (salmer dog ofte i den af Gr. sidst redigerede form). Da udgaven antagelig tilsigter at give et centralt, repræsentativt udvalg af Gr.s produktion, aabner dette et vidt spillerum for kritik, da hver Gr.-kender og -elsker har sin mening om, hvad der burde medtages $i$ et saadant udvalg. - De bibliografiske oplysninger til de forskellige tekster kunde være lidt fyldigere, og især kunde kildeangivelserne $\mathrm{i}$ digtbindene $\mathrm{i}$ ikke faa tilfælde nok have været lidt mere præcise. Et samlet register til hele værket savnes. 
ordningen i en kommende fuldstændig udgave. Jeg tror heller ikke, at man ved studiet af komplette udgaver af andre store forfattere, danske eller udenlandske, kan lære synderligt, dertil er Gr. et altfor enestaaende og særpræget fænomen. Der er sikkert intet andet at gøre end at begynde »paa bar bund« og lade udgaven tage form af det givne materiale, dog med størst muligt hensyn til det føromtalte litterære princip, hvilket vil sige, at de af Gr. selv til trykken befordrede skrifter olgn. og Gr.s efterladte papirer udgives i 2 forskellige serier fra først til sidst. De til de trykte skrifter bevarede manuskripter, udkast osv. konsulteres eller medtages naturligvis i første serie, saaledes at begrebet 》efterladte papirer《 alene kommer til at betyde optegnelser, hvortil der intet tilsvarende tryk haves fra Gr.s haand. Af disse papirer kan saa f. eks. Gr.s utrykte prædikener og breve danne særskilte underserier, men derpaa og paa hundreder af lignende og meget vanskeligere spørgsmaal skal jeg ikke her nærmere indlade mig. 